\title{
Performance Appraisal Satisfaction and Counterproductive Behaviors: Direct and Moderating Effects
}

\author{
Hasan M. Aleassa ${ }^{1}$ \\ ${ }^{1}$ Faculty of Economics and Administrative Sciences, Yarmouk University, Jordan \\ Correspondence: Hasan M. Aleassa, Faculty of Economics and Administrative Sciences, Yarmouk University, \\ Jordan. E-mail: Haleassa@gmail.com
}

Received: November 13, 2013

Accepted: December 29, $2013 \quad$ Online Published: January 12, 2014

doi:10.5430/ijba.v5n1p76

URL: http://dx.doi.org/10.5430/ijba.v5n1p76

\begin{abstract}
In recent years, there is an increasing attention in counterproductive behaviors. We developed a model that explains the influence of performance appraisal satisfaction on counterproductive behaviors. Moreover, three moderators (exchange ideology, hostile attribution style, and fatalism) were incorporated in the model. The model was tested on a sample of bank employees. The results supported three out of four hypotheses of this study. As predicted, performance appraisal and counterproductive behaviors were negatively associated. Additionally, the results suggested that exchange ideology, hostile attribution, but not fatalism, moderated the direct effect of appraisal satisfaction on counterproductive behaviors. Lastly, limitations, implications, and recommendation for future studies are discussed.
\end{abstract}

Keywords: appraisal satisfaction, exchange ideology, hostile attribution, fatalism, counterproductive behaviors, Jordan

\section{Introduction}

Human resource is essential for any organization's future performance. This suggests that individuals' positive contribution is paramount for organizations' survival and is increasingly considered a source of sustainable competitive advantage (Wright, Dunford, \& Snell, 2001). Thus, management better utilization and leveraging of this valuable resource would be reflected positively on the firm's ability to create more value and achieve a competitive performance (Pfeffer \& Veiga, 1999).

Therefore, organizations desire and ask their employees to display functional behaviors, such as innovation and organizational citizenship behaviors that contribute significantly toward helping organizations achieve their goals. Accordingly, much of researchers' attention has focused on positive contributions employees make to their organization (Fleet \& Griffin, 2006). It should be noted, however, that there is another set of behaviors organizations prefer not to be exhibited by their employees because they might inhibit or limit the organization ability to successfully meet their goals (Griffin \& Lopez, 2005). As a result, researchers have begun to give more attentions to these misconducts. Accordingly, a more recent trend of research has emerged focusing attention on bad behaviors; "counterproductive behaviors" (CPBs) is a term used to describe such behaviors (Kelloway, Francis, Prosser, \& Cameron, 2010).

Thus, to enhance their competitiveness, organizations' attention should not only be focused on behaviors that might produce the desired outcomes, but also they should pay more attention to behaviors that might impede their occurrence (Levine, 2010). For this reason, this type of behaviors is receiving a growing interest among researchers and practitioners as well. The impetus for this growing interest is the evident increasing prevalence and the consequent cost of this kind of behaviors (Kidwell \& Martine, 2005; Penney \& Spector, 2005; Lawrence \& Robinson, 2007; Jensen, Opland, \& Ryan, 2010). Identifying antecedents and understanding how they relates to CPBs is of theoretical and practical importance. On one hand, this will enhance our understanding of this harmful behavior, and on the other hand, will help practitioners to deal with such behaviors more effectively. An extensive review of literature revealed that numerous individual and situational antecedents have been investigated (Marcus \& Schuler, 2004; for good review see Martinko, Gundlach, \& Douglas, 2002; and Lau, Au, \& Ho, 2003). However, to the best of our knowledge there is no previous study explored the effect of human resource practices on employees CPBs. Therefore, this study is designed to investigate the effect of performance appraisal satisfaction on CPBs. 
Fletcher (2001) noted that the view that all ratees would react the same way to appraisal is probably unsafe. A moderator is a variable that affect the relationship between other two variables (Baron \& Kenny, 1986). Therefore, in addition to the direct effect the current study will examine the potential moderating effect of three variables, fatalism, exchange ideology, and hostile attribution style, on the direct effect of appraisal satisfaction on CPBs. Investigating this kind of relationship will help us to better understand the effect of appraisal satisfaction on CPBs under various moderating conditions, thus enable us to get more practical results.

\section{Performance Appraisal}

The central role human resources practices play in achieving competitive advantage is acknowledged and evident (Schuler \& MacMillan, 1984; Guthrie, Flood, Liu, \& MacCurtain, 2009; Progoulaki \& Theotokas, 2010). This role is even more crucial nowadays where organizations struggle to respond to a highly dynamic competitive environment. One of the most important human resource practices is performance appraisal (Boswell \& Boudreau, 2000)

The principal goal of performance appraisal is to assess employees' performance and contribution with the intention to positively influence individual and organizational long term effectiveness (DeNisis \& Gonzalez, 2000). This is made possible through providing clear feedback on performance to employees alongside with suggestions for improvements to enhance their motivation and capabilities (Jawahar, 2006; Youngcourt, Leiva, \& Jones, 2007). An effective performance appraisal system not only can identify skill needs deficiencies and address them by the appropriate training and development programs, but also can unearth hidden talents (Montague, 2007). Hence, performance appraisal is of crucial importance to both individuals and organizations because of its potential effects on organizational effectiveness and variety of attitudes and behaviors of interest to organizations (Jawahar,2006; 2007; Ahmed, Hussain, Ahmed, \& Akbar, 2010).

Therefore, much research effort has been devoted to find out ways to improve performance appraisal system and make it more successful and positive to employees and their organizations (Heathfiels, 2007). Early research on performance appraisal is widely skewed toward improving the psychometric prosperities of the rating system. In addition, Bernardin, Hagan, Kane, and Villanova (1998) indicated that "the appraisal of performance appraisal is not good" (p.3). Research figures indicate that only about $10 \%$ of employees indicated that their organization's formal appraisal system helps them to improve performance (Pulakos, 2004; cited in DeNisi \& Pritchard, 2006). Moreover, research reported that most of UK organizations surveyed (about 80\%) expressed some degree of dissatisfaction with their performance appraisal system (Cook \& Crossman, 2004). Taken together, all of these observations and findings indicate that appraisal systems failed to achieve the intended outcomes.

One Plausible explanation for this is that having technically sound appraisal system is not enough for these results to accrue. Some researchers noted that the impact of human resource management practices on employees' behaviors and attitudes depends on their perception and evaluation of those practices (Hartog, Boselie, \& Paauwe, 2004). In the same vein Jawahar (2007) suggested that effectiveness of appraisal system depends not only on valid and reliable rating but also on employee reactions. Yet, one area of research that has received little attention is employee reaction to performance appraisal (Kuvaasa, 2007; 2011). One of the reactions that has become of increasing interest to researchers is appraisal satisfaction (Keeping \& Levy, 2000). Employee satisfaction with performance appraisal plays a critical role in determining its long term effectiveness. This notion is well expressed in Cardy and Dobbins (1994) assertion that "with dissatisfaction and feelings of unfairness in process and inequity in evaluations, any appraisal system will be doomed to failure" (p. 54). In the same realm, some researchers argue that reaction criteria can't be underestimated, and that negative reaction toward performance appraisal may ruin the most carefully constructed appraisal system (Cardy \& Dobbins, 1994; Murphy \& Cleveland, 1995). If ratees are dissatisfied with performance appraisal or perceived it as unfair, they will be less likely to use evaluation feedback to improve their performance. Thus, Cawley, Keeping, \& Levy (1998) legitimately concluded that "it seems reasonable to expect that subordinates' reactions to appraisal systems would have just as much impact on the success and effectiveness of an appraisal system as the more technical aspects of the system" (p.615). Moreover, they cited assertion that, by and large, ratees' reactions are better indicators of the overall effectiveness of appraisal system than psychometric properties.

Although performance appraisal has realized a considerable increase in use and interest, there is shortage of research aimed at understanding employees' responses to its process and developing ways to mange these responses (Holbrook, 2002). Montague, (2007) Noted "that poorly conducted appraisals can seed staff insecurity and encourage dissent or anger " (p.42). A state which is associated with negative employee reactions (Reisel, Probst, Chia, Maloles, \& König, 2010; Nederlof, Muris, \& Hovens, 2013). Furthermore, Holbrook (2002) concluded that "what is missing now is "a model that will reduce the pressures for supervisors and subordinates to engage in counter productive 
behaviors that limit the effectiveness of performance evaluations" (p. 103). Thus, despite the commonly accepted belief that performance appraisal serves significant function for organizations, it may also have some dysfunctions, that is, it produces conditions that are counterproductive to organization. There is an ample evidence to suggest that satisfaction is negatively related to CPBs (Dalal, 2005; Mount, Ilies, \& Johnson, 2006), however there is paucity of research investigating the impact of appraisal satisfaction on CPBs. This omission is astonishing given the fact that almost all organizations have formal appraisal system to evaluate their employees' performance. Hence, this study is significant contribution to the literature as it fills this void in this field of study. In addition to the direct effect we tested the moderating effect of fatalism, exchange ideology, and hostile attribution style on the appraisal-satisfaction relationship.

\section{Counterproductive Behaviors}

Acts on the side of employees that are damaging to organizations' goals is receiving a growing attention. This notoriety is often attributed to the strong potential that this set of behaviors has to create harmful and destructive consequences to organizations (lau et al., 2003). Counterproductive behaviors is a label used to describe this class of behaviors which is defined as any voluntary act on the part of an organization member that violate organizational norms and are viewed by the organization as contrary to its legitimate interests (Sackett, 2002; Jensen et al., 2010). Counterproductive behaviors is an umbrella term that includes a set of behaviors that includes but not limited to theft, aggression, dishonesty, absenteeism, sabotage, and withdrawal (Martinko et al., 2002; Sackett, 2002; Judge, Scott, \& Ilies, 2006; Spector, Fox, Penney, Bruursema, \& Kessler, 2006; Spector \& Fox, 2010). Marcus and Schuler (2004) suggested three criteria for a behavior to be labeled as counterproductive. First, is the requirement that the behavior under consideration must be volitional in the sense that the behavior is under volitional control and involves choice and willingness. Second; the behavior must have the potential to produce a predictable harms but not necessarily need to result in actual harm. Third, the behavior of interest must be contrary to legitimate interest but not be outweighed by potential legitimate interests.

An effort has been made to explain the underlying structure of CPBs. An early attempt in this regard was offered by Robinson and Bennett (1995). Using a multidimensional scaling technique they identified two main categories of CPBs based on the target of these behaviors. Their study indicated that the CPBs can be directed at either the organization or individuals. Bennett and Robinson (2000) confirmed this categorization.

All types of $\mathrm{CPBs}$ share the common feature of being potentially harmful to organizations or their employees. Therefore, scholars assert that CPBs is detrimental factor for an organization's success (Levine, 2010). Hence, a considerable research effort has been expended to understand the determinants of these behaviors (Jensen et al., 2010). This research effort has resulted in a wide array of antecedents associated with CPBs. These antecedents are categorized into individual and situational variables (Lau, et al., 2003). A closer look at the extant literature shows that one neglected, yet important, variable that would impact employees' engagement in CPBs is appraisal satisfaction. Thus, a goal of this study is to extend the extant literature on CPBs by examining whether appraisal satisfaction explains variance in CPBs.

\section{Hypotheses Development}

\subsection{Appraisal Satisfaction- Counterproductive Behaviors}

Dissatisfaction is a negative assessment of one's job or job experience. According to "disconfirmation of expectations" paradigm, satisfaction is a function of the gap between prior expectations and actual outcome received (Esbjerg et al., 2012). Accordingly, employees' satisfaction with their appraisal is determined by the size of the gap between their prior expectations and the actual rating they received. When employee expectations about how well they performed are not congruent with their actual performance rating, appraisal dissatisfaction usually result. Of course the sense of dissatisfaction is "inherently unpleasant, and therefore motivates disaffected employees to search for means for reducing dissatisfaction" (Rosse \& Miller, 2000, p. 5). Dissatisfaction evokes a set of different behaviors from which unhappy employee might choose to adapt or cop with this discomfort state. Subsequently, individuals will resort for different types of behaviors to adapt to the painful and unpleasant state of dissatisfaction (Griffeth, Gaertner, \& Sager, 1999).

To reiterate, performance appraisal benefits both organizations and their employees. On the employees side performance rating might affect several aspects of employees' career life such as new job assignment and promotion opportunities. Receiving dissatisfying performance evaluation may be perceived as an obstacle which might delay or inhibit achievement of those desired outcomes. Spector (1978) argued and cited other authors (Krech \& Krutchfield, 1948; Eaton, 1952) for the view that unfulfilled needs of employees, due to inadequate financial compensation and 
lack of promotion opportunities, would result in frustration. Moreover, he mentioned that "any goal or desired end state that is blocked... involves an instance of frustration" (p. 816). Stauss, Schmidt, \& Schoeler, (2005) indicated that " frustration is the special case of a strongly felt dissatisfaction, which appears if individuals do not reach goals that were thought as feasible or do not get rewards that were pledged" (p. 234).

The frustration results from unfulfilled desires will result in aggressive behavior targeted either at individual or organization (perceived source of frustration) (Storms and Spector, 1987). Thus, being dissatisfied with performance appraisal connotes that a desired target is thwarted by an external part which "induce feelings of anger and frustration, and subsequently to CWB" (Spector \& Fox, 2002, p. 277). Previous studies draw a significant relationship between satisfaction and destructive behavior (Kulas, Mclnnerney, Demuth, \& Jadwinski, 2007; Omar et al., 2011). Therefore we forward the following hypothesis:

H1: Appraisal satisfaction is negatively related to counterproductive behaviors.

\subsection{Hostile Attribution Style}

Attribution theory is concerned with how people make casual explanation. That is people seek for an answer for the questions that start with the "why?" (Kelley, 1973). Attributions are typically made when important, unexpected, surprising events occur, especially in ambiguous situations where the causes of an important outcome are not clear (Harvey, Harris, \& Martinko, 2008). In the context of this research, hostile attribution style is relevant as this style is associated with the stable tendency to make external attribution; that is the tendency to assign responsibility for their failure on external element such as other persons or situational circumstances rather than to themselves (Aquino, Doguglas, \& Martinko, 2004). Individuals who possess this style "are more likely to interpret the act of others as hostile, and therefore reciprocate with additional hostility" (Klotz \& Buckley, 2010, p 575). Weiner (1995) noted that individuals who attribute causes of negative outcome to external factors are more likely to react aggressively. Research evidence is accumulating to support the proposition that employees with hostile attribution style are more prone to engage in CPBs (Douglas \& Martinko, 2001; Homant \& Kennedy, 2003). Thus, the following hypothesis is proposed:

H2: Hostile attribution style will moderate the relationship between appraisal satisfaction and counterproductive behaviors in such a way that this relationship to be stronger for individuals who exhibit more hostile attribution style.

\subsection{Fatalism}

One important distinctive feature of Arab society is the belief in fate (Hammoud, 2011). There is more than one form of fatalism and several typologies are available, however we limit our focus on theological fatalism. In this regard fatalism is a psycho-spiritual construct which can be defined as the belief that God or any other supernatural agent controls one's destiny and the outcome of his actions (Kayani, King, \& Flieiter, 2011). Thus fatalistic persons will perceive that what happens to them in their daily life is predetermined and inescapable. Hence, fatalism beliefs would influence individuals' perception of the causes of life events.

Indeed, Kardiner (1939) remarked that "the belief in fate shifts the responsibility from those who actually have power or advantages and places it upon a kind of mechanistic conception of human destiny. The chief function of the belief is to compel the individual to accept his role in life, and not bother those who exploit him; though he is given some right to attempt to alter his fate. If this fails, he has only fate to blame'” (p. 314). What happened is the God's will. Therefore, individuals with such belief would view unfavorable events or wrongdoings committed on them as indispensable, and it is beyond his, or any other person, control. If there is that belief about the underlying main cause of unacceptable events (i.e. unacceptable performance appraisal), an employee would refrain from retribution against their managers or organizations. Previous empirical evidence indicate that fatalism constitutes a barrier to participation in health promoting practices such as accepting beneficial medical treatment of some diseases and cancer screening (Spurlock \& Cullins, 2005; Jun \& Oh, 2013). Other studies suggested that unfortunate and disadvantageous individuals rationalize their position through religious fatalism (Patwary, O'Hare, Elahi, \& Hassan, 2010). Another study (Patwary, O'Hare, \& Sarker, 2012) reported that individuals with high fatalistic beliefs attributed occupational accidents to fate. Following this line of reasoning we propose the next hypothesis:

H3: Fatalism will moderate the relationship between appraisal satisfaction and counterproductive behaviors in such a way that this relationship to be stronger among individuals with low fatalistic beliefs.

\subsection{Exchange Ideology}

Exchange ideology is about peoples' belief concerning reciprocity (Lin, 2007). This suggests that individuals base their attitudes and behaviors on the favorableness of treatment received from their organizations. Eisenberger, 
Huntington, Hutchison, \& Sowa (1986) defined this concept as "the strength of an employee's belief that work effort should depend on treatment by the organization" (p. 503), and conceptualized it as continuum. On one end those with strong exchange ideology would feel more compelled to respond in accordance with the perceived way they are being treated by the exchange partner. On the other end individuals with weak exchange ideology would do and behave almost the same regardless of what they receive from their organizations.

For individuals with strong exchange ideology, the emphasis is on the balanced exchange of not only benefits but also on the exchange of injuries. Thus, we posit that employees high in exchange ideology when receive satisfactory appraisal will feel that their effort has been recognized and appreciated, and hence feel more obligated to repay their organization with more valuable contribution. Yet, receiving perceived poor appraisal would lead those employees to feel justified to engage in CPBs at the workplace as response to perceived unfavorable treatment. Whereas individuals low on exchange ideology would behave consistently across all situations no matter of rating outcome. Extant literature has provided empirical evidence of the moderating effect of exchange ideology (Lin, 2007; Sze \& Angeline, 2011). On these premises we offer the following hypothesis:

H4: Exchange ideology will moderate the relationship between appraisal satisfaction and counterproductive behaviors in such a way that this relationship to be stronger among individuals with a strong exchange ideology.

\section{Methodolgy}

\subsection{Participants}

Data for this study was collected from employees working in five commercial banks located at the northern governorate of Jordan. Surveys were distributed to 296 full time employees. Of them 281 were completed and returned. Five surveys were excluded because they were not fully completed. The remaining 276 yielded a response rate of $93 \%$. With regard to marital status about $63 \%$ of the respondents were either married or engaged. Approximately, $75 \%$ were male. In terms of participants' age, about $76 \%$ of respondents were less than 40 years old. Lastly, of the total participants approximately $68 \%$ had up to 10 years experience.

\subsection{Measure}

Performance appraisal satisfaction was measured using twelve items scale developed by dobbins, Cardy, \& Platz-Vieno (1990). Responses were rated on a 7- point likert scale, ranging from 1 (strongly disagree) to 7 (strongly agree). A sample item is "my appraisal was what I expected". Counterproductive behaviors construct was assessed by multiple items adapted from previously validated measures (Skarlicki \& Folger, 1997; Bennett \& Robinson, 2000; Jones, 2009). The resulting measure consisted of 14 items referencing different types of CPBs some of which targeted at the organization and others directed at employees' direct supervisor. Respondents reported the extent to which they performed each act with the relevant item on a seven point scale ranged from 1 (never) to 7 (daily). A sample item of those behaviors is "taking property from work without permission".

We utilized Eisenberger, Armeli, Rexwinkel, Lynch, \& Rhoades (2001) scale to measure employee exchange ideology. The scale consists of eight items, these items were coded on a seven point scale anchored by the two end points strongly disagree (1) and strongly agree (7). An example item is "An employee's work effort should not depend on of his or her pay".

Seven items adapted from prior research (Acevedo, 2008; Khamis, 2008; Somer, Klein-Sela, \& Or-Chen, 2011) were used to assess fatalism. Participants were instructed to report their degree of agreement or disagreement with each item on a seven point scale, ranging from 1 (strongly disagree) to 7 (strongly agree). A sample item is "The incidents of my life are due simply to fate".

Hostile attribution style was assessed with six items adapted from organizational attributional style questionnaire (OASQ) (Kent \& Martinko, 1995). Each item depicting a negative hypothetical workplace scenario such as "you recently received a below average performance evaluation from your supervisor". There was two response items for each scenario assessing the locus of causality and stability dimensions of this construct. Responses for the first dimension were recorded on a seven point scale ranging from 1 (completely due to me) to 7 (completely due other people or circumstances). Responses for the second dimension were on a seven point scale ranged from (1) never present to (7) always present.

\section{Results}

We used simple regression to test for the direct effect of appraisal satisfaction on CPBs. Moderated hierarchical regression analysis was conducted to test the moderating effect of our three hypothesized moderators on the relationship between appraisal satisfaction and CPBs. To test for the moderating effect an interaction term of the 
predictor and the moderator should be created. To reduce multicollinearity potential we centered, the two main effects (the independent variable and the moderator) before we created the interaction terms (Cohen \& Cohen, 1983). In the regression analysis the interaction terms were entered after the main predictors. We concluded that a moderator hypothesis would be supported whenever a significant interaction, as evident by a statistically significant beta coefficient for the interaction term, was detected (Baron and Kenny, 1986).

Statistical analysis results are presented in table (1). The results of our statistical analysis show that a significant negative relationship exists between appraisal satisfaction and counterproductive behaviors, $(B=-.654, p<001)$. The results of the regression also indicated that appraisal satisfaction explained a significant proportion of variance in CPBs $\left(\mathrm{R}^{2}=606, \mathrm{~F}(1,274)=421.462, \mathrm{p}<.001\right)$. Moreover the results of moderated hierarchical regression analysis provided support for the moderating effect of exchange ideology $\left(B=, 089, \Delta \mathrm{R}^{2}=.006, \mathrm{~F}_{\text {change }}(1,272)=4.89, \mathrm{P}<.05\right)$ and hostile attribution $\left(\mathrm{B}=.094, \Delta \mathrm{R}^{2}=.007, \quad \mathrm{~F}_{\text {change }}(1,272)=5.644, \quad \mathrm{P}<.01\right)$ on the appraisal satisfaction-counterproductive behaviors relationship. The $\mathrm{R}^{2}$ change indicating that the interaction between appraisal satisfaction and the moderators (exchange ideology and hostile attribution) explained a significant amount of the variation in stated counterproductive behaviors beyond and above that explained by the significant predictor (appraisal satisfaction) alone. However, the moderating effect of fatalism on the relationship between appraisal satisfaction and counterproductive behaviors was not supported.

In sum, the direct effect of appraisal satisfaction on counterproductive behaviors was supported. Moreover, results showed that this relationship was significantly moderated by exchange ideology and hostile attribution and these effects were in the predicted direction. However, the results of regression analysis did not provide sufficient statistical evidence to support the moderating effect of fatalism hypothesis.

Table 1. Simple and moderated hierarchical regression results

\section{Statistics}

\begin{tabular}{|c|c|c|c|c|c|c|c|c|}
\hline Analysis & step & variables & B & t-value & $\mathbf{R}^{2}$ & $\Delta \mathbf{R}^{2}$ & F- change & df \\
\hline 1 & 1 & ApSat & -.654 & $-20.53 * * *$ & .606 & .606 & 421.462 & 1,274 \\
\hline \multirow[t]{3}{*}{2} & \multirow[t]{2}{*}{1} & ApSat & -.488 & $-12.131 * * *$ & \multirow[t]{2}{*}{.654} & \multirow[t]{2}{*}{.654} & \multirow[t]{2}{*}{257.791} & \multirow[t]{2}{*}{2,273} \\
\hline & & HosAtt & .297 & $6.139 * * *$ & & & & \\
\hline & 2 & ApSat*Hos & .094 & $2.376^{* *}$ & .661 & .007 & 5.644 & 1,272 \\
\hline \multirow[t]{3}{*}{3} & 1 & ApSat & -.652 & $-20.347 * * *$ & \multirow[t]{2}{*}{606} & \multirow[t]{2}{*}{.606} & \multirow[t]{2}{*}{210.279} & \multirow[t]{2}{*}{2,273} \\
\hline & & Fat & .025 & .5 & & & & \\
\hline & 2 & ApSat*Fat & .01 & .245 & .606 & .000 & .06 & 1,272 \\
\hline \multirow[t]{3}{*}{4} & 1 & ApSat & -.531 & $-13.836^{* * *}$ & \multirow[t]{2}{*}{.642} & \multirow[t]{2}{*}{.642} & \multirow[t]{2}{*}{244.833} & \multirow[t]{2}{*}{2,273} \\
\hline & & ExId & .221 & $5.242 * * *$ & & & & \\
\hline & 2 & ApSat*ExId & .089 & $2.211^{*}$ & .648 & .006 & 4.89 & 1,272 \\
\hline
\end{tabular}

ApSat $=$ Appraisal satisfaction, HosAtt $=$ Hostile attribution, Fat $=$ Fatalism, ExId $=$ Exchange ideology.

\section{Discussion}

Counterproductive behaviors are prevalent and costly problem. Gaining better and deeper understanding of its antecedents will enhance our ability to curtail such behavior. This study extended literature by examining an important, but neglected, antecedent of CPBs that is appraisal satisfaction. Moreover, we explored underinvestigated question of whether appraisal satisfaction-counterproductive behaviors association is moderated by individual variables.

The finding of the study provided support for the hypothesis that appraisal satisfaction has a negative impact on CPBs. This result is in line with prior research findings obtained in different contexts (Omar et al., 2011; Geddes \& Baron, 1997; Kuvaas, 2006). For example, Geddes and Baron, (1997) found that giving negative feedback promoted aggressive responses from the recipient employees. Pearce and Porter, (1986) noted that formal appraisal might be considered as a type of feedback. Kuvaas (2006) and Ahmed et. al., (2010) reported that appraisal satisfaction is negatively associated with turnover intention. 
The negative direct effect of appraisal satisfaction on CPBs indicates that the intensity of felt dissatisfaction increases the likelihood of employee engagement in counterproductive behaviors. This result is informative and points to the importance of taking appraisal satisfaction more seriously. Employees usually consider their performance to be above average (Pearce and porter, 1986) and rate their performance at higher level than their supervisors do (Arnold \& Davey, 1992). One study found that the average self-rating of the participants was at the $78^{\text {th }}$ percentile. Moreover, the same study reported that about $85 \%$ of the subjects saw their manager's rating as lower than that of their own (Meyer, 1980). This clearly point to the unrealistic expectation about their performance, thereby widening the gap between the perceived self performance and the manager rating, a state which exacerbate the tendency for employees to engage in CPBs. Therefore, correcting this inflated expectation would bring employees' expectations closer to reality, and therefore reduce the likelihood that dissatisfaction due to unrealistic expectation will result. According to disconfirmation model, satisfaction is a function of disparity between prior expectations and actual rating. Thus, the greater the discrepancy the lower the level of the satisfaction, a state which in its turn will lead to enhancement of CPBs. This underscores the importance of ongoing and timely feedback to employees. Performance feedback should occur frequently during the evaluation period rather than limiting it to once a year. Ongoing ratee-rater interactions would unveil the employee-managers discrepancies and give mangers an opportunity to reconcile it early enough, subsequently enhancing appraisal satisfaction.

Furthermore, consistent with the hypothesis, the results provided support for the moderating effect of hostile attribution and exchange ideology on the appraisal satisfaction-counterproductive behaviors relationship. These findings are consistent with results reported by other authors (Ellis, Weiss, \& Lochman, 2009; Chiu \& Peng, 2008). For example, Chiu and Peng (2008) found hostile attribution style moderate the effect of psychological contract breach on employees' deviance in such a way that the higher the hostile attribution style the stronger the positive effect of psychological contract breach on employee deviance.

Hostile attribution is a perceptual response to ambiguous situation (Gentile \& Bushman, 2012). In an ambiguous situation, in which accurate concrete information is lacking, individuals form beliefs on the basis of inference. These inferences are more often than not fail to reflect the reality of the situation, hence the consequent perception may be inaccurate (Brunk, 2010). This suggests that limited communication and feedback would provide the basis for inaccurate causality. Managers are reluctant to give negative feedback so they tend to sandwich negative feedback between two layers of positive comments (Dohrenwend, 2002). This will create a situation in which ambiguity is elevated and thus hostile attribution is activated. When the causes of an outcome are clear the effect is unlikely. Therefore, providing detailed and accurate explanations concerning the reasons upon which the appraisal is based would remove ambiguity and promote a more objective casual explanation, subsequently avoid hostile attribution effect.

In addition, the moderation analysis showed that employees with strong exchange ideology are more inclined to engage in CPBs in response to their perception of unfavorable and unfair rating given the effort they have put forth. Some researchers argue that "fairness" is an integral part of satisfaction and that satisfaction responses can be interpreted as fairness judgments (Dobbins et al., 1990; Organ, 1988). Fairness is perceived rather than objective reality (Greenberge, 1990). Previous studies found that employees consider not only numerical rating in responding to performance appraisal (Greenberg, 1991), explanation facilitated acceptance of unpleasant events (e.g. less than acceptable appraisal) (Wanberg, Gavin, \& Bunce, 1999; Gilliland et al, 2001).Thus, providing employees detailed justification for their rating may serve as a useful mechanism for enhancing employees' acceptance of less than favorable appraisal results, and hence show less negative reciprocity to unpleasant appraisal, subsequently reduce their tendency to engage in CPBs.

Results, however, did not confirm the moderating effect of fatalism on the relation between performance appraisal satisfaction and CPBs. This result might be attributed to the lack of variability in this construct as the mean and the standard deviation of fatalism were 4.98 and .75 respectively. Most Jordanian people are religious and that religion has a significant role in their lives (Droeber, 2003; Moaddel and Azadarmaki, 2002). Thus asking about religious fatalism might prime such beliefs and affected their responses. Therefore, in the context of religious countries, future models might replace fatalism with either perceived behavioral control (Ajzen, 2002) or locus of control (Rotter, 1966) as they might be better constructs to measure the extent to which an individual believes he has control over his own fate.

\section{Limitations and Future Studies}

This study, as any other study, is not without limitations. These limitations are avenues for future research to develop more rigorous studies. The first limitation is that in this study data on the predictor and criterion variables were 
provided by the same source, this may raise concern about the potential for common method variance. However, some researchers argue that the effect of this problem has been exaggerated and overstated and suggest that this problem may be mythical rather than fact (Spector, 1987; Crampton \& Wagner, 1994). Fortunately, Doty and Glick (1998) concluded that "common methods bias does affect the estimates of the correlations among substantive constructs, but not so frequently as to invalidate all research findings... Thus, many of the criticisms of research streams that rely predominantly on a single data collection procedure are overstated" (p. 98). This idea is corroborated by Malhorta, Kim, \& Patil (2006) who analyzed previously published studies in the information system area and found that such problem is not substantial.

This does not mean that we should ignore the existence of this problem. Cross-sectional studies adopting self reported measure may increase the possibility of this problem (Spector, 2006) making common method variance an issue for behavioral studies. Some effort should be made to avoid such potential bias by every possible mean. Extant research has suggested several procedural and statistical methods to deal with this problem (Podsakoff, MacKenzie, \& Lee, 2003,). In this study several procedural steps such as respondents' anonymity, clear instructions to assure respondents that there is no correct or wrong answer, constructs were measured with different scale formats (e.g., Likert-type and categorical scales) and with different scale anchors, the inclusion of several reverse items, and lastly, using previously validated instruments were adopted to address common method bias effect. However, statistical techniques were not used in this study. The most commonly used statistical technique is Harman's (1967) single factor test, thus future studies are advised to use such techniques.

The second limitation concerns the social desirability bias. Self report survey is likely to be susceptible to social desirability which might undermine the validity of information obtained (Cohen, Pant, \& Sharp, 1993). However, in social science and behavioral studies self report surveys are the most common method of data collection (Malhorta et al. 2006). Podsakoff and Organ (1986) contented that "it seems that organizational researchers do not like self-reports, but neither can they do without them.... [thus] self-reports are here to stay" (p.531). Moreover, some researchers suggested that self-report is more accurate method to assess the actual degree of CPBs than supervisor or coworker reports, that's due to the fact that most of $\mathrm{CPBs}$ are enacted in private rather than public, therefore workers are more knowledgeable of their covert behaviors than their supervisor and coworkers (Jensen et al., 2010; Fox, Spector, Goh, \& Bruursema, 2007). In this study to address and to mitigate the effect of social desirability and encourage respondents to express their true responses and subsequently to feel less need to answer in socially desirable way several precautions were adopted. Respondents were assured that their responses are anonymous, and were informed that there is no wrong or right answer and were urged to answer objectively and honestly (Bowling \& Eschleman, 2010). Previous studies (Fisher, 1993) found that indirect questioning (projective questions or scenario based survey) is a valid technique for reducing social desirability bias. So, future studies are advised to use this technique.

However, while some studies (Bruk-lee \& Spector, 2006) found convergence between self-reports and others-reports of CPBs, other studies found that convergence was better for CPBs targeting organization than persons (fox et al., 2007). Thus, we recommend that future studies solicit counterproductive data from multiple sources (workers, peers, supervisors) in order to fully capture the CPBs domain.

The third limitation relates to the sample of the study. The fact that data was collected only from a sample of bank workers and that the majority of our sample were men may limit the generalizability of results to women and other organizational settings. Thus we urge future studies to test this model on a sample of women or more representative sample in other organizational settings.

A fourth limitation is related to the use of cross sectional design. Data for this study was collected at single point of time this prevents us from making inferences of causality. Thus, longitudinal and experimental designs are recommended for future studies.

Lastly, based on the target; CPBs can be categorized into two main categories: those targeting the organization or the individuals. In the context of our model this might be based on the perceived source of dissatisfaction with the performance appraisal. Yet, we did not consider this categorization in our model. Therefore, future studies are encouraged to extend the current model by testing the hypothesis that the type of CPBs adopted depends on who is held accountable for the unfavorable rating received. In the same vein future studies might incorporate additional variable not considered in the current study such as attitude toward supervisor, trust in supervisor, and organizational justice, to enhance the predictive power of the model. 


\section{References}

Acevedo, G. A. (2008). Islamic fatalism and the clash of civilizations: An appraisal of contentious and dubious theory. Social Forces, 86(4), 1711-1752. http://dx.doi.org/10.1353/sof.0.0033

Ahmed, A., Hussain, I., Ahmed, S., \& Akbar, M. F. (2010). Performance appraisals impact on attitudinal outcomes and organizational performance. International Journal of Business and Management, 5(10), 62-68.

Ajzen, I. (2002). Perceived behavioral control, self-efficacy, locus of control, and the theory of planned behavior. Journal of Applied Social Psychology, 32(4), 665-683. http://dx.doi.org/10.1111/j.1559-1816.2002.tb00236.x

Aquino, K., Douglas, S., \& Martinko, M., J. (2004). Overt Anger in response to victimization: Attributional style and organizational norms as moderators. Journal of Occupational Health Psychology, 9(2), 152-164. http://dx.doi.org/10.1037/1076-8998.9.2.152

Arnold, J., \& Davey, K. M. (1992). Self - ratings and supervisor ratings of graduate employees' competences during early career. Journal of Occupational and Organizational Psychology, 65(3), 235-250. http://dx.doi.org/10.1111/j.2044-8325.1992.tb00501.x

Baron, R. M., \& Kenny, D. A. (1986). The moderator-mediator variable distinction in social psychological research: Conceptual, strategic, and statistical considerations. Journal of personality and social psychology, 51(6), 1173-1182. http://dx.doi.org/10.1037/0022-3514.51.6.1173

Bennett, R. J., \& Robinson, S. L. (2000). Development of a measure of workplace deviance. Journal of Applied Psychology, 85(3), 349. http://dx.doi.org/10.1037/0021-9010.85.3.349

Bernardin, J., Hagan, C., Kane, J., \& Villanova, P. (1998). Effective performance management: A focus on precision, customers, and situational constraints. In J. Smither (Ed.), Perform-ance appraisal. State of the art in practice (pp.3-48). San Francisco: Jossey-Bass Publishers.

Boswell, W. R., \& Boudreau, J. W. (2000). Employee satisfaction with performance appraisals and appraisers: The role of perceived appraisal use. Human resource Development Quarterly, 11(3), 283-299. http://dx.doi.org/10.1002/1532-1096(200023)11:3<283::AID-HRDQ6>3.0.CO;2-3

Bowling, N. A., \& Eschleman, K. J. (2010). Employee personality as a moderator of the relationships between work stressors and counterproductive work behavior. Journal of Occupational Health Psychology, 15(1), 91-103. http://dx.doi.org/10.1037/a0017326

Bruk-Lee, V., \& Spector, P. E. (2006). The social stressors-counterproductive work behaviors link: Are conflicts with supervisors and coworkers the same? Journal of Occupational Health Psychology, 11(2), 145-156. http://dx.doi.org/10.1037/1076-8998.11.2.145

Brunk, K. H. (2010). Exploring origins of ethical company/brand perceptions-A consumer perspective of corporate ethics. Journal of Business Research, 63(3), 255-262. http://dx.doi.org/10.1016/j.jbusres.2009.03.011

Cardy, R., L., \& Dobbins, G., H. (1994). Performance appraisal: Alternative perspective. Cincinati, OH: South-Western Publishing.

Cawley, B. C., Keeping, L., \& Levy, P. E. (1998). Participation in the performance appraisal process and employee reaction: A meta-analytic review of field investigations. Journal of applied psychology, 83(4), 615-633. http://dx.doi.org/10.1037/0021-9010.83.4.615

Chiu, S. F., \& Peng, J. C. (2008). The relationship between psychological contract breach and employee deviance: The moderating role of hostile attributional style. Journal of Vocational Behavior, 73(3), 426-433. http://dx.doi.org/10.1016/j.jvb.2008.08.006

Cohen, J. \& Cohen, P. (1983). Applied multiple regression/correlation analysis science. Hillsdale, NJ: Erlbaum.

Cohen, J., Pant, L., \& Sharp, D. (1993). A validation and extension of a multidimensional ethics scale. Journal of Business Ethics, 12(1), 13-26. http://dx.doi.org/10.1007/BF01845782

Cook, J., \& Crossman, A. (2004). Satisfaction with performance appraisal system: A study of role perception. Journal of managerial psychology, 19(5), 526-541. http://dx.doi.org/10.1108/02683940410543605

Crampton, S. M., \& Wagner, J. A. (1994). Percept-percept inflation in microorganizational research: An investigation of prevalence and effect. Journal of Applied Psychology, 79(1), 67-76. http://dx.doi.org/10.1037/0021-9010.79.1.67 
Dalal, R., S. (2005). A meta-analysis of the relationship between organizational citizenshipbehavior and counterproductive work behavior. Journal of applied Psychology, 90(6), 1241-1255. http://dx.doi.org/10.1037/0021-9010.90.6.1241

DeNisi, A., \& Pritchard, R. (2006). Performance appraisal, Performance management and improving individual performance: A motivational framework Management and organization Review, 2(2), 253- 277. http://dx.doi.org/10.1111/j.1740-8784.2006.00042.x

DeNisi, A., S., \& Gonzalez, J., A. (2000). Design performance appraisal systems to improve performance. In E. A. Locje (Ed.), Handbookof principles of organizational behavior (pp.60-72). Oxford: Blackwell

Dobbins, G. H., Cardy, R. L., \& Platz-Vieno, S. J. (1990). A contingency approach to appraisal satisfaction: An initial investigation of the joint effects of organizational variables and appraisal characteristics. Journal of Management, 16(3), 619-632. http://dx.doi.org/10.1177/014920639001600307

Dohrenwend, A. (2002). Serving Up the Feedback Sandwich Negative feedback is never easy to give, but sandwiching criticism between layers of praise makes it more palatable and more effective. Family Practice Management, 9(10), 43-46.

Doty, D. H., \& Glick, W. H. (1998). Common methods bias: Does common methods variance really bias results? Organizational Research Methods, 1, 374-406. http://dx.doi.org/10.1177/109442819814002

Douglas, S., C., \& Martinko, M., J. (2001). Exploring the role of individual differences in the prediction of workplace aggression. Journal of Applied Psychology, 86(4), 547-559. http://dx.doi.org/10.1037/0021-9010.86.4.547

Droeber, J. (2003). Woman to woman"- the significance of religiosity for young women in Jordan. Women's Studies International Forum, 26(5), 409-424. http://dx.doi.org/10.1016/j.wsif.2003.08.006

Eisenberger, R., Armeli, S., Rexwinkel, B., Lynch, P. D., \& Rhoades, L. (2001). Reciprocation of perceived $\begin{array}{lllll}\text { organizational support. Journal of applied psychology, } & 86(1), \quad 42-51 .\end{array}$ http://dx.doi.org/10.1037/0021-9010.86.1.42

Eisenberger, R., Huntington, R., Hutchison, S., \& Sowa, D. (1986). Perceived organizational support. Journal of Applied Psychology, 71(3), 500-507. http://dx.doi.org/10.1037/0021-9010.71.3.500

Ellis, M.L., Weiss, B., \& Lochman, J.E. (2009). Executive functions in children: Associations with aggressive behavior and appraisal processing. $J$ Abnormal Child Psychology, 37(7), 945-956. http://dx.doi.org/10.1007/s10802-009-9321-5

Esbjerg, L., Jensen, B., B., Bech-Larsen, T., Barcellos, M., D., Boztug, Y., \& Grunert, K. (2012). An integrative conceptual framework for analyzing customer satisfaction with shopping trip experiences in grocery retailing. Journal of Retailing and Customer Services, 19(4), 445-456. http://dx.doi.org/10.1016/j.jretconser.2012.04.006

Fisher R. J. (1993). Social desirability bias and the validity of indirect questioning. Journal of consumer research, 20, 303-315. http://dx.doi.org/10.1086/209351

Fleet, D. D., \& Griffin, R. W. (2006). Dysfunctional organization culture: The role of leadership in motivating dysfunctional work behaviors. Journal of Managerial Psychology, 21(8), 698-708. http://dx.doi.org/10.1108/02683940610713244

Fletcher, C. (2001). Performance appraisal and Management: The developing research agenda. Journal of Occupational and organizational Psychology, 74(4), 473-487. http://dx.doi.org/10.1348/096317901167488

Fox, S., Spector, P. E., Goh, A., \& Bruursema, K. (2007). Does your coworker know what you're doing? Convergence of self-and peer-reports of counterproductive work behavior. International Journal of Stress Management, 14(1), 41. http://dx.doi.org/10.1037/1072-5245.14.1.41

Geddes, D., \& Baron, R. A. (1997). Workplace aggression as a consequence of negative performance feedback. Management Communication Quarterly, 10, 433-454. http://dx.doi.org/10.1177/0893318997104002

Gentile, D. A., \& Bushman, B. J. (2012). Reassessing media violence effects using a risk and resilience approach to understanding aggression. Psychology of Popular Media Culture, 1(3), 138-151. http://dx.doi.org/10.1037/a0028481 
Gilliland, S. W., Groth, M., Baker, R. C., Dew, A. E., Polly, L. M., \& Langdon, J. C. (2001). Improving applicants' reactions to rejection letters: an application of fairness theory. Personnel Psychology, 54(3), 669-703. http://dx.doi.org/10.1111/j.1744-6570.2001.tb00227.x

Greenberg, J. (1990). Employee theft as a reaction to underpayment inequity: The hidden cost of pay cuts. Journal of applied psychology, 75(5), 561. http://dx.doi.org/10.1037/0021-9010.75.5.561

Greenberg, J. (1991). Using explanations to manage impressions of performance appraisal fairness. Employee Responsibilities and Rights Journal, 4(1), 51-60. http://dx.doi.org/10.1007/BF01390438

Griffeth, R., W., Gaertner, S., \& Sager, J., K. (1999). Taxonomic model of withdrawal behaviors: The adaptive response model. Human Resource Management Review, 9(4), 577-590. http://dx.doi.org/10.1016/S1053-4822(99)00034-0

Griffin, R., W., \& Lopez, Y., P. (2005). "Bad behavior" in organizations: A review and typology for future research. Journal of management, 31(6), 988-1005. http://dx.doi.org/10.1177/0149206305279942

Guthrie, J. P., Flood, P. C., Liu, W., \& macCurtain, S. (2009). High performance work systems in Ireland: Human resource and organizational outcomes. International Journal of Human resource management, $20(1), 112-125$. http://dx.doi.org/10.1080/09585190802528433

Hammoud, J. (2011). Consultative authority decision making: On development and characterization of Arab corporate culture. International journal of business and social Science, 2(9), 141-148.

Hartog, D., Boselie, P., \& Paauwe, J. (2004). Performance management : a model and research agenda. Applied psychology, 53(4), 556-569. http://dx.doi.org/10.1111/j.1464-0597.2004.00188.x

Harvey, P., harris, K., J., \& Martinko, M., J. (2008). The Mediated influence of hostile attributional style on turnover intentions. Journal of Business Psychology, 22(4), 333-343. http://dx.doi.org/10.1007/s10869-008-9073-1

Heathfield, S. (2007). Performance appraisals don't work-What does? The journal For Quality \& Participation, $30(1), 6-9$.

Holbrook Jr, R. L. (2002). Contact points and flash points: Conceptualizing the use of Justice mechanisms in the performance appraisal interview. Human resource Management Review, 12(1), 101-123. http://dx.doi.org/10.1016/S1053-4822(01)00053-5

Homant, R. J., \& Kennedy, D. B. (2003). Hostile attribution in perceived justification of workplace aggression. Psychological Reports, 92(1), 185-194. http://dx.doi.org/10.2466/pr0.2003.92.1.185

Jawahar, I, M. (2006). An investigation of potential consequences of satisfaction with appraisal feedback. Journal of leadership and organizational Studies, 13(2), 14-28. http://dx.doi.org/10.1177/10717919070130020101

Jawahar, I, M. (2007). The influence of perceptions of fairness on performance appraisal reactions. Journal of Labor research, 28(4), 735-754. http://dx.doi.org/10.1007/s12122-007-9014-1

Jensen, J., M., Opland, R., A., \& Ryan, A., M. (2010). Psychological contracts and counterproductive work behaviors: Employee responses to transactional and relational breach. Journal of Business Psychology, 25(4), 555-568. http://dx.doi.org/10.1007/s10869-009-9148-7

Jones, D. A. (2009). Getting even with one's supervisor and one's organization: relationships among types of injustice, desires for revenge, and counterproductive work behaviors. Journal of Organizational Behavior, 30(4), 525-542. http://dx.doi.org/10.1002/job.563

Judge, T. A., Scott, B. A., \& Ilies, R. (2006). Hostility, job attitudes, and workplace deviance: test of a multilevel model. Journal of Applied Psychology, 91(1), 126. http://dx.doi.org/10.1037/0021-9010.91.1.126

Jun, J., \& Oh, K. M. (2013). Asian and Hispanic Americans' Cancer Fatalism and Colon Cancer Screening. American Journal of Health Behavior, 37(2), 145-154. http://dx.doi.org/10.5993/AJHB.37.2.1

Kardiner, A. (1939). The individual and his society. New York: Columbia University.

Kayani, A., King, M., J., \& Flieiter, J., J. (2011). Fatalism and road safety in developing countries, with a focus on Pakistan. Journal of the Australasian College of Road Safty, 22(2), 41-47.

Keeping, L. M., \& Levy, P.E. (2000). Performance appraisal reactions: Measurement, modeling, and method bias. Journal of applied psychology, 85(5), 708-723. http://dx.doi.org/10.1037/0021-9010.85.5.708 
Kelley, H. H. (1973). The processes of causal attribution. American psychologist, 28(2), 107-128. http://dx.doi.org/10.1037/h0034225

Kelloway, E. K., Francis, L., Prosser, M., \& Cameron, J. E. (2010). Counterproductive work behavior as protest. Human Resource Management Review, 20(1), 18-25. http://dx.doi.org/10.1016/j.hrmr.2009.03.014

Kent, R., \& Martinko, M. J. (1995). The development and evaluation of a scale to measure organizational attribution style. In M. J. Martinko (Ed.), Attribution theory:An organizational perspective (pp. 53-75). Delray Beach, FL: St. Lucie Press.

Khamis, V. (2008). Post-traumatic stress and psychiatric disorders in Palestinian adolescents following intifada-related injuries. Social Science \& Medicine, 67(8), 1199-1207. http://dx.doi.org/10.1016/j.socscimed.2008.06.013

Kidwell, R. E., \& Martin, C. L. (2005). The prevalence (and ambiguity) of deviant behavior at work. Managing organizational deviance, 1-21.

Klotz, A., C., \& Buckley, M., R. (2010). Where everybody knows your name: Lessons from small business about preventing workplace violence. Business Horizon, 53(6), 571-579. http://dx.doi.org/10.1016/j.bushor.2010.06.004

Kulas, J.T., McInnerney, J.E., Demuth, R.F., \& Jadwinski, V. (2007). Employee satisfaction and theft: testing climate perceptions as a mediator. The Journal of Psychology, 141(4), 389-402. http://dx.doi.org/10.3200/JRLP.141.4.389-402

Kuvaas, B. (2006). Performance appraisal satisfaction and employee outcomes: mediating and moderating roles of work motivation. The International Journal of Human Resource Management, 17(3), 504-522. http://dx.doi.org/10.1080/09585190500521581

Kuvaas, B. (2007). Different relationships between perceptions of developmental performance appraisal and work performance. Personnel Review, 36(3), 378-397. http://dx.doi.org/10.1108/00483480710731338

Kuvaas, B. (2011). The interactive role of performance appraisal reactions and regular feedback. Journal of Managerial Psychology, 26(2), 123-137. http://dx.doi.org/10.1108/02683941111102164

Lau, V., C., S., Au, W., T., \& Ho, J., M., C. (2003). A qualitative and quantitative review of antecedents of counterproductive behavior in organizations. Journal of Business and Psychology, 18(1), 73-99. http://dx.doi.org/10.1023/A:1025035004930

Lawrence, T., B., \& Robinson, S., L. (2007). Ain't misbehavin: Workplace deviance as organizational resistance. Journal of Management, 33(3), 378-394. http://dx.doi.org/10.1177/0149206307300816

Levine, E., L. (2010). Emotion and power (as social influence): Their impact on organizational citizenship and counterproductive individual and organizational behavior. Human resource management Review, 20(1), 4-17. http://dx.doi.org/10.1016/j.hrmr.2009.03.011

Lin, C., P. (2007). To share or not to share: Modeling Knowledge sharing using exchange ideology as a moderator. Personnel Review, 36(3), 457-475. http://dx.doi.org/10.1108/00483480710731374

Malhotra, N. K., Kim, S. S., \& Patil, A. (2006). Common method variance in IS research: A comparison of alternative approaches and a reanalysis of past research. Management Science, 52(12), 1865-1883. http://dx.doi.org/10.1287/mnsc.1060.0597

Marcus, B., \& Schuler, H. (2004). Antecedents of counterproductive behavior at work: A general perspective. Journal of Applied Psychology, 89(4), 647-660. http://dx.doi.org/10.1037/0021-9010.89.4.647

Martinko, M. J., Gundlach, M. J., \& Douglas, S. C. (2002). Toward an integrative theory of counterproductive workplace behavior: A causal reasoning perspective. International Journal of Selection and Assessment, 10(1-2), 36-50. http://dx.doi.org/10.1111/1468-2389.00192

Meyer, H. H. (1980). Self - Appraisal of Job Performance. Personnel Psychology, 33(2), 291-295. http://dx.doi.org/10.1111/j.1744-6570.1980.tb02351.x

Moaddel, M., \& Azadarmaki, T. (2002). The worldviews of Islamic publics: The cases of Egypt, Iran, and Jordan. Comparative Sociology, 1(3-4), 299-319. http://dx.doi.org/10.1163/156913302100418619

Montague, N. (2007). The Performance appraisal: A powerful management tool. Management Quarterly, 48(2), 40-53. 
Mount, M, Ilies, R., \& Johnson, E. (2006). Relationship of personality traits and counterproductive work behaviors: The mediating effects of job satisfaction. Personnel psychology, 59(3), 591-622. http://dx.doi.org/10.1111/j.1744-6570.2006.00048.x

Murphy, K. R., \& Cleveland, J. N. (1995). Understanding performance appraisal: Social, organizational, and goal-based perspectives. Thousand Oaks, CA: Sage.

Nederlof, A. F., Muris, P., \& Hovens, J. E. (2013). Anger, anxiety, and feelings of delusional threat as predictors of aggressive attitudes: An experimental mood induction study in a non-clinical sample. Personality and Individual Differences.

Omar, F., Halim, F. W., Zainah, A. Z., Farhadi, H., Nasir, R., \& Khairudin, R. (2011). Stress and job satisfaction as antecedents of workplace deviant behavior. 12, (Special Issue of Social and Psychological Sciences for Human Development), 46-51.

Organ, D. W. (1988). A restatement of the satisfaction-performance hypothesis. Journal of Management, 14(4), 547-557. http://dx.doi.org/10.1177/014920638801400405

Patwary, M. A., O’Hare, W. T., \& Sarker, M. H. (2012). Occupational accident: An example of fatalistic beliefs among medical waste workers in Bangladesh. Safety science, 50(1), 76-82. http://dx.doi.org/10.1016/j.ssci.2011.07.004

Patwary, M. A., O'Hare, W. T., Elahi, K. M., Hassan, M. M., \& Sarker, M. H. (2010). Domes and the Dead: an example of extreme fatalism among mortuary workers in Bangladesh. Kaleidoscope: The Interdisciplinary Postgraduate Journal of Durham University's Institute of Advanced Study, Afterlives, 4(1), 10-18.

Pearce, J. L., \& Porter, L. W. (1986). Employee responses to formal performance appraisal feedback. Journal of Applied Psychology, 71(2), 211-218. http://dx.doi.org/10.1037/0021-9010.71.2.211

Penney, L., \& Spector, P. (2005). Job stress, incivility, and counterproductive work behavior (CWB): The moderating role of negative affectivity. Journal of Organizational Behavior, 26(7), 777-796. http://dx.doi.org/10.1002/job.336

Pfeffer, J., \& Veiga, J., F. (1999). Putting people first for organizational success. Academy of management executive, $13(2), 37-48$.

Podsakoff, P. M., \& Organ, D. W. (1986). Self-reports in organizational research: Problems and prospects. Journal of management, 12(4), 531-544. http://dx.doi.org/10.1177/014920638601200408

Podsakoff, P. M., MacKenzie, S. B., \& Lee, J.Y. (2003). Common method biases in behavioral research: A critical review of the literature and recommended remedies. Journal of Applied Psychology, 88(5), 879-903. $\mathrm{http}: / / \mathrm{dx}$.doi.org/10.1037/0021-9010.88.5.879

Progoulaki, M., \& Theotokas, L. (2010). Human resource management and competitive advantage: An application of resource-based view in the shipping industry. Marine Policy, 34(3), 575-582. http://dx.doi.org/10.1016/j.marpol.2009.11.004

Pulakos, E. D. (2004). A Roadmap for Developing, Implementing, and Evaluating Performance Management Systems. Alexandria, VA: SHRM Foundation.

Reisel, W. D., Probst, T. M., Chia, S. L., Maloles, C. M., \& König, C. J. (2010). The effects of job insecurity on job satisfaction, organizational citizenship behavior, deviant behavior, and negative emotions of employees. International Studies of Management and Organization, 40(1), 74-91. http://dx.doi.org/10.2753/IMO0020-8825400105

Robinson, S., L., \& Bannett, R., J. (1995). A typology of deviant workplace behaviors: A multidimensional scaling study. Academy of management Journal. 38(2), 555-572. http://dx.doi.org/10.2307/256693

Rosse, J., G., \& Miller, H., E. (2000). Toward a comprehensive model of the employee adaptation decision process. A paper presented at the Annual meeting of the Western Decision Sciences Institute. Maui, Hawaii.

Rotter, J. B. (1966). Generalized expectancies for internal versus external control of reinforcement. Psychological monographs: General and applied, 80(1), 1-28. http://dx.doi.org/10.1037/h0092976

Sackett, P. R. (2002). The structure of counterproductive work behaviors: Dimensionality and relationships with facets of job performance. International Journal of Selection and Assessment, 10(1/2), 5-11. $\mathrm{http}: / / \mathrm{dx}$.doi.org/10.1111/1468-2389.00189 
Schuler, R. S., \& MacMillan, I. C. (1984). Gaining competitive advantage through human resource management practices. Human resource Management, 23(3), 241-255. http://dx.doi.org/10.1002/hrm.3930230304

Skarlicki, D. P., \& Folger, R. (1997). Retaliation in the workplace: The roles of distributive, procedural, and interactional justice. Journal of Applied Psychology, 82(3), 434-443. http://dx.doi.org/10.1037/0021-9010.82.3.434

Somer, E., Klein-Sela, C., \& Or-Chen, K. (2011). Beliefs in Reincarnation and the Power of Fate and Their Association With Emotional Outcomes Among Bereaved Parents of Fallen Soldiers. Journal of Loss and Trauma, 16(5), 459-475. http://dx.doi.org/10.1080/15325024.2011.575706

Spector, P. E. (1978). Organizational frustration: A model and review of the literature. Personnel Psychology, 31(4), 815-829. http://dx.doi.org/10.1111/j.1744-6570.1978.tb02125.x

Spector, P. E. (1987). Method variance as an artifact in self-reported affect and perceptions at work: Myth or $\begin{array}{lllll}\text { significant problem? Journal of Applied Psychology, } & \text { 72, }\end{array}$ http://dx.doi.org/10.1037/0021-9010.72.3.438

Spector, P. E. (2006). Method variance in organizational research: Truth or urban legend? Organizational Research Methods, 9, 221-232. http://dx.doi.org/10.1177/1094428105284955

Spector, P., E., \& Fox, S. (2002). An emotion-centered model of voluntary work behavior: Some parallels between counterproductive work behavior and organizational citizenship behavior. Human Resource management review, 12(2), 269-292. http://dx.doi.org/10.1016/S1053-4822(02)00049-9

Spector, P., E., \& Fox, S. (2010). Theorizing about the deviant citizen: An attributional explanation of the interplay of organizational citizenship and counterproductive work behavior. Human Resource Management Review, 20(2), 132-143. http://dx.doi.org/10.1016/j.hrmr.2009.06.002

Spector, P., E., Fox, S., Penney, L., M., Bruursema, A., G., \& Kessler, S. (2006). The dimensionality of counterproductivity: Are all counterproductive behaviors equal. Journal of Vocational Behavior, 68(3), 446-460. http://dx.doi.org/10.1016/j.jvb.2005.10.005

Spurlock, W. R., \& Cullins, L. S. (2005). Cancer fatalism and breast cancer screening in African American women. The ABNF journal, 17(1), 38-43.

Stauss, B., Schmidt, M., \& schoeler, A. (2005). Customer frustration in loyalty programs. International Journal of service industry management, 16(3), 229-252. http://dx.doi.org/10.1108/09564230510601387

Storms, P. L., \& Spector, P. E. (1987). Relationships of organizational frustration with reported behavioral reactions: The moderating effect of perceived control. Journal of Occupational Psychology, 60, 227-234. http://dx.doi.org/10.1111/j.2044-8325.1987.tb00255.x

Sze, C. C., \& Angeline, T. (2011). Engaging employees to their jobs: Role of exchange ideology as a moderator. African Journal of Business Management, 5(10), 3986-3994.

Wanberg, C. R., GAVIN, M. B., \& BUNCE, L. W. (1999). Perceived fairness of layoffs among individuals who have been laid off: A longitudinal study. Personnel Psychology, 52(1), 59-84. http://dx.doi.org/10.1111/j.1744-6570.1999.tb01813.x

Weiner, B. (1995). Judgments of responsibility: A foundation for a theory of social conduct. New York: Guilford.

Wright, P. M., Dunford, B., B., \& Snell, S., A. (2001). Human resources and the resource-based view of the firm. Journal of Management, 27(6), 701-721. http://dx.doi.org/10.1177/014920630102700607

Youngcourt, S., S., Leiva, P., I., \& Jones, R., G. (2007). Perceived purposes of performance appraisal: correlates of individual-and position-focused purposes on attitudinal outcomes. Human resource Development Quarterly, 18(3), 315-343. http://dx.doi.org/10.1002/hrdq.1207 